DOI: https://doi.org//10.32839/2304-5809/2020-83.1-2

УДК 378.018.43.02:004

Агейчева А.О., Деркунська Ж.В., Агейчева О.О.

Національний університет «Полтавська політехніка імені Юрія Кондратюка»

\title{
ЛІНГВІСТИЧНІ АСПЕКТИ ПЕРЕКЛАДУ АНГЛІЙСЬКОЇ НАУКОВО-ТЕХНІЧНОЇ ТЕРМІНОЛОГІЇ
}

\begin{abstract}
Анотація. Стаття є оглядом найбільш значних досліджень з проблем перекладу англійської науковотехнічної термінології. Представлені класифікація та аналіз труднощів, що виникають при перекладі, пояснені їх основні причини. Пропонуються шляхи вирішення проблем перекладу науково-технічних термінів. Доведено, що вирішальне значення у технічному перекладі має правильна інтерпретація термінів, які містять ключову інформацію. Досліджено деякі стилістично-граматичні особливості англійського тексту, невластиві стилю української технічної літератури. Визначено причини труднощів у процесі аналізу зовнішньої форми і структурної організації терміну, інтерференція рідної мови, внутрішньомовна омонімія. У ході вирішення поставлених завдань було виявлено, що термінологія є окремою лексичної категорією, ключовим аспектом якої є термін, який у більшості вивчених нами робіт визначається як одиниця мови, що вживаеться для позначення спеціальних понять і явищ.
\end{abstract}

Ключові слова: науково-технічна термінологія, переклад, стилістично-граматичні особливості.

Ageicheva Anna, Derkunska Zhanna, Aheicheva Oleksandra National University «Yuri Kondratyuk Poltava Polytechnic»

\section{ENGLISH SCIENTIFIC AND TECHNICAL TERMINOLOGY TRANSLATION LINGUISTIC ASPECTS}

Summary. The article is an overview of the most significant research on the problems of translation in English scientific and technical terminology. The classification and analysis of difficulties encountered in translation are presented, their main reasons are explained. Ways of solving problems of translation scientific and technical terms are offered. It is proved that the correct interpretation of terms that contain key information is crucial in technical translation. Some stylistic and grammatical features of the English text, which are not peculiar to the style of Ukrainian technical literature, are investigated. The causes of difficulties in the process of analysis of the external form and structural organization of the term interference of the mother tongue, intrinsic homonymy, foreign to the language translation form of the term, complex structural organization of the term. The basic properties of the term were also revealed, such as systematicity, uniqueness, out-of-context, lack of emotional coloring, informativeness. The specificity of the term, which distinguishes it from other words of the language, is a special purpose, the function of the term - whenever possible to clearly call special concepts. As professionalism is used to refer to certain concepts only in the sphere of a particular profession, crafts, crafts, they do not always meet the standards of literary language. For the most part, professionalism is used in the oral informal speech of people of a particular profession. In the terminology studied, the thematic principle distinguishes different in terms of volume and structure of the group of technical terms, combined semantically and functionally on the basis of the connection of objects and phenomena of reality, which they denote in the language of translation the form of the term, complex structural organization of the term. Source of formation of terminological information is practical creative activity of people, social and cognitive experience. This defines the social essence of terminological information, which concentrates the collective profile-scientific memory, the basic units of which are concepts. The formation of a new concept is often associated with a new perception of the subject, which is understood on the basis of available language experience

Keywords: scientific and technical terminology, translation, stylistic and grammatical features.

Постановка проблеми. Сучасна термінологія - досить складний і неоднорідний лексичний пласт. Попри твердження про однозначність, конкретність, чіткість і ясність термінів, багато 3 них не можуть вважатися такими, оскільки вони є багатозначними і мають синоніми. Межі між термінологічною і нетермінологічною лексикою часто розмиті. Водночас, стрімкий розвиток термінологічних сфрер практично всіх наук призводить до того, що в сучасній термінологї з'являеться велика кількість нових лексичних одиниць. Подібні терміни починають широко використовуватися, проте їх фіксація в словниках дещо спізнюеться, що створює необхідність знання та вмілого застосування перекладацьких прийомів під час їх перекладу.

Аналіз останніх досліджень і публікацій. Оскільки основними рисами українського технічного стилю є сувора ясність викладу, чіткість визначень, лаконічність форми, А.В. Федоров визначив повноцінність перекладу як «вичерпну передачу смислового змісту оригіналу і повну фрункціонально-стилістичну відповідність йому» [1], то, працюючи зі спеціальними текстами, перекладач зобов'язаний правильно зрозуміти і адекватно передати мовою перекладу всю інформацію, закладену в оригіналі.

Вирішальне значення у технічному перекладі має правильна інтерпретація термінів, які містять ключову інформацію. Теоретично переклад термінів не повинен викликати будь-яких ускладнень. Однак, оскільки сучасна термінологія являе собою досить складний і неоднозначний пласт лексики, на практищі ми переконалися, що термінологічні одиниці часто є серйозною перешкодою для правильного розуміння і перекладу спеціальних текстів. Аналіз труднощів перекладу $є$ важливим для навчання іноземної мови, 
«Молодий вчений" • № 7.1 (83.1) • липень, 2020 р.

оскільки він «е одним із способів оцінки викладачем ефрективності навчання і визначення, на що слід звернути увагу в майбутньому» [2]. Щоб вичерпно передати зміст, необхідно правильно зрозуміти сенс термінологічної одинищі, а також «співвідношення між змістом і фрормою» [3, с. 121] оригіналу, і підібрати відповідний еквівалент у мові перекладу. При цьому Ю.Н. Марчук закликає не протиставляти синтаксис і семантику у визначенні частин мови і членів речення, а «розглядати ці два аспекти у тісному зв'язку і в їх маніфрестації у контексті» [4, с. 42]. Перешкодою для розуміння може стати як фрорма терміну, так і зміст укладеного в зовнішньо зрозумілій фрормі поняття. Нерідко підбір відповідного еквівалента в мові перекладу також є нелегким завданням для починаючого перекладача.

Формулювання мети статті. Визначення деяких стилістично-граматичних особливостях англійського тексту, невластивих стилю української технічної літератури.

Виділення не вирішених раніше частин загальної проблеми. Форма терміну є важливим елементом для його розуміння. Розглянуто труднощі, пов'язані 3 форомю терміну. Форма $€$ невід'ємною частиною семантичної структури будь-якого слова.

Виклад основного матеріалу дослідження.

1. В англійському тексті переважають особові форми дієслова, тоді як українському науковому стилю більш властиві безособові або невизначено-особові звороти, наприклад: You might ask why engineers have generally chosen to supply us with a.c. rather than d.c. for our household needs. - Можно запитати, чому для домашніх потреб зазвичай використовується змінний, а не постійний ток. We know the primary coil in the ordinary transformer to have more turns than the secondary one. - Відомо, що первинна обмотка звичайного трансформатора має більше витків, ніж вторинна.

2. В англійських текстах описового характеру нерідко вживаеться майбутній час для вираження теперішньої дії.

Керуючись контекстом, слід перекладати такі пропозищії не майбутнім, а теперішнім часом, іноді з модальним відтінком: The zinc in the dry cell accumulates a great many excess electrons which will move to the carbon electrode. - Цинк в сухому елементі акумулюе велике число надлишкових електронів, що рухаються до вугільного електроду. Fig. 10 gives a drawing of a bulb; the filament will be seen in the centre. - На рис. 10 наводиться креслення електричної лампи; нитку розжарення видно в центрі.

3. В англійських технічних текстах особливо часто зустрічаються пасивні звороти, тоді як в українській мові пасивний стан вживається значно рідше.

Отже, під час перекладу нам часто доводиться вдаватися до заміни пасивних конструкцій іншими засобами вираження, більш властивими українській мові [5, с. 184]. This question was discussed at the conference. - Це питання було обговорено на конфреренції. - Це питання обговорювалося на конфреренції. - Це питання обговорювали на конференції. - Конференція обговорювала (або: обговорила) це питання.
4. Автори англійської технічної літератури широко використовують різні скорочення, які абсолютно не вживаються в українській мові, наприклад: d.c. (Direct current) - nостійний струл; a.c. (Alternating current) - злінний струл; s.a. (Sectional area) - плоша перерізу; b.p. (Boiling point) точка кипіння та ін.

Такі скорочення в перекладі повинні розшифровуватися і даватися в повному позначенні.

5. Деякі слова або вирази в англійському тексті містять чужий нашій мові образ. Під час перекладу вони повинні замінюватися аналогами, тобто виразами, відповідними за змістом, але більш звичними для українського тексту, наприклад:

We have learned to manufacture dozens of construction materials to substitute iron.

Замість dozen - «тузіны» в українській мові звичайно в таких випадках вживається слово десяток, тому це речення ми перекладаємо так:

«Ми навчилися виробляти десятки будівельних литеріалів, шо залінюють залізо».

Будь-який предмет або явище асоціюються у нас з їх вербальним позначенням у рідній мові. Стосовно іноземної мови, ми можемо не знати того чи іншого слова, проте його форма часто допомагає нам по асоціації з рідною мовою, або ж на основі вже відомих нам слів іноземною мовою ми можемо зрозуміти його без словника. Н.I. Шахова, вивчаючи питання розуміння слів у процесі читання, виділила три їх категорії:

- слова, розуміння яких відбувається через усвідомлення їхньої графіки;

- слова, розуміння яких відбувається через усвідомлення їхньої структури;

- слова, розуміння яких відбувається через розуміння їхнього контексту [6, с. 124].

Подібна класифрікація повною мірою стосуеться термінів. Так, до першої групи можна віднести весь комплекс інтернаціональних термінів, форми яких у мовах оригіналу та перекладу схожі. Наприклад, схожа графрічна фрорма терміну process - npoиес допомагає зрозуміти його значення в тексті. Що стосуеться терміну expert, то хоча для його перекладу краще використовувати український еквівалент "спеціаліст», замість запозичення "експерт», фрорма англійського терміну є і в цьому випадку ключем для правильного трактування [7, с. 27].

До термінів, розуміння яких відбувається через контекст, відносяться багатозначні слова і словосполучення, реалії, терміни та слова, які набули нового значення у спеціальному контексті, так звані конотовані терміни. Аналіз контексту при роботі 3 подібними термінами необхідний для їх правильного перекладу [8, с. 31].

Під час перекладу термінів важливо враховувати багато фракторів, однак якщо правильно виділено той елемент, який допомагає встановити послідовність між відомим і новим, це можна вважати першим кроком до правильного розуміння. Усі види аналізу терміна: компонентний, словотвірний, морфологічний, контекстуальний полегшують розуміння терміну. Стосовно термінів, що відносяться до перших двох груп, то грамотно проведений аналіз форми терміну в цьму випадку найчастіше призводить до його розуміння і вірного перекладу [9, с. 38].

Однак досить часто інтерференція рідної мови сильно заважає роботі перекладача [10, с. 7]. 
В.В. Алімов називає «дві будь-які значущі одиниці (морфеми, слова, вирази, речення), які за звучанням / написанням та функціями в одній мові нагадують відповідні одинищі і фрункції в іншій мові» [11, с. 15] інтерферентами і виділяе як позитивні, так і негативні інтердеренти. «Мовна інтерференція визначається як взаємодія мовних систем в умовах двомовності, що формується або за взаємодії різномовних соціумів, або у разі індивідуального білінгвізму». «Основною причиною деструктивної інтерференції у технічному перекладі є недостатня або надмірна ідентифікація якихось лінгвістичних i спеціальних явищ i фрункцій в одній мові i ïx компенсація схожими, на думку перекладача, явищами і функціями у іншій мові» [11, с. 22].

Висновки i перспективи дослідження. Як відомо, джерелом формування термінологічної ін- формащії $є$ практична творча діяльність людей, суспільно-пізнавальний досвід. Цим визначається соціальна сутність термінологічної інфрормації, яка конщентруе в собі колективну профрільно-наукову пам'ять, базовими одиницями якої виступають поняття. Формування нового поняття нерідко пов'язане із новим сприйняттям предмета, який розуміеться на базі наявного мовного досвіду. Перекладач повинен вивчити ту область науки і техніки, в якій він працюе. Це дає йому можливість домогтися вичерпного розуміння змісту понять, що виражені термінами. Недостатня обізнаність у тій галузі знання, до якої відноситься текст, що перекладається веде до нерозуміння терміну, незважаючи на те, що його форма може бути зрозуміла або навіть знайома перекладачеві. Перспективу подальших досліджень також вбачаємо в аналізі інших труднощів, що виникають під час перекладу.

\section{Список літератури:}

1. Федоров А.В. Основы общей теории перевода. Лингвистические проблемы : учебное пособие. Москва : Высш. школа, 2009. 396 с.

2. Алимов В.В. Явление лингвистической интерференции при изучении специального перевода : авторефр. дис. канд. фрилолог. наук. Москва : МГУ, 2008. 24 с.

3. Нелюбин Л.Л. Введение в технику перевода (когнитивный теоретико-прагматический аспект) : учебное пособие. Москва : Изд-во МГОУ, 2005. 153 с.

4. Марчук Ю.Н. Проблемы машинного перевода : учебное пособие. Москва : Наука, 2008. 232 с.

5. Ковтун О.В. Особливості перекладу англійських авіаційних термінів українською мовою. Матеріали III міжн. наук.-практ. конфб. ["Соціокультурні та етнолінгвістичні проблели галузевого перекладу в парадиглі євроінтеграції»], (2-3 квітня 2010 р.). Київ : АграрМедіаГруп, 2010. С. 182-186.

6. Шахова Н.И. Вопросы обучения пониманию слов в процессе чтения. Лингвистика и летодика преподавания иностранного языка. Москва : Наука, 2006. С. 124-128.

7. Рябцева Н.К. Перевод как специальная речевая деятельность. Проблемы перевода текстов разных типов. Москва : Ин-т языкознания, 2007. С. 22-35.

8. Кучман I. Переклад англійських термінів у галузі комп'ютерних технологій. Вісник Житолир. держ. ун-ту імені Івана Франка. 2005. Вип. 10. С. 25-32.

9. Корбут О.Г. До проблеми труднощів перекладу технічних термінів у студентів машинобудівних спеціальностей. Advanced Education. 2014. Вип. 1. С. 36-41.

10. Смірнова Т.В. Лексичні прийоми перекладу термінологічних одиниць транспортної галузі (Нац. авіаційний ун-т, м. Київ). URL: http://er/nau/edu/ua

11. Алимов В.В. Явление лингвистической интерференции при изучении специального перевода : автореф. дис. канд. фрилолог. наук. Москва : МГУ, 2008. 24 с.

\section{References:}

1. Fedorov A.V. (2009). Osnovy obshhej teorii perevoda. Lingvisticheskie problemy: uchebnoe posobie [Fundamentals of general translation theory. Linguistic problems: a textbook]. Moskva: Vyssh. shkola, $396 \mathrm{~s}$.

2. Alimov V.V. (2008). Yavlenie lingvisticheskoj interferenczii pri izuchenii speczial'nogo perevoda [The phenomenon of linguistic interference in the study of special translation]: avtoref. dis. kand. filolog. nauk. Moskva: MGU, 24 s.

3. Nelyubin L.L. (2005). Vvedenie v tekhniku perevoda (kognitivny j teoretiko-pragmaticheskij aspekt): uchebnoe posobie [Introduction to the technique of translation (cognitive theoretical and pragmatic aspect): a textbook]. Moskva: Izd-vo MGOU, 153 s.

4. Marchuk Yu.N. (2008). Problemy mashinnogo perevoda: uchebnoe posobie [Problems of machine translation: a textbook]. Moskva: Nauka, 232 s.

5. Kovtun O.V. (2010). Osoblyvosti perekladu anhliiskykh aviatsiinykh terminiv ukrainskoiu movoiu [Features of the translation of English aviation terms into Ukrainian]. Materialy III mizhn. nauk.-prakt. konf. [«Sotsiokulturni ta etnolinhvistychni problemy haluzevoho perekladu v paradyhmi yevrointehratsii»], (2-3 kvitnia 2010 r.). Kyiv: AhrarMediaHrup, s. 182-186.

6. Shakhova N.I. (2006). Voprosy obucheniya ponimaniyu slov v proczesse chteniya [Questions of learning to understand words in the process of reading]. Lingvistika i metodika prepodavaniya inostrannogo yazyka. Moskva: Nauka, s. 124-128.

7. Ryabczeva N.K. (2007). Perevod kak speczialnaya rechevaya deyatelnost [Translation as a Special Speech Activity]. Problemy perevoda tekstov raznykh tipov. Moskva: In-t yazykoznaniya, s. 22-35.

8. Kuchman I. (2005). Pereklad anhliiskykh terminiv u haluzi kompiuternykh tekhnolohii [Translation of English Terms in Computer Technology]. Visnyk Zhytomyr. derzh. un-tu imeni Ivana Franka, vyp. 10, s. $25-32$.

9. Korbut O.H. (2014). Do problemy trudnoshchiv perekladu tekhnichnykh terminiv u studentiv mashynobudivnykh spetsialnostei [On the Problem of Difficulties in Translation of Technical Terms in Students of Mechanical Engineering Specialties]. Advanced Education, vyp. 1, s. 36-41.

10. Smirnova T.V. Leksychni pryiomy perekladu terminolohichnykh odynyts transportnoi haluzi [Lexical methods of translation of terminological units of the transport industry] (Nats. aviatsiinyi un-t, m. Kyiv). URL: http://er/nau/edu/ua

11. Alimov V.V. (2008). Yavlenie lingvisticheskoj interferenczii pri izuchenii speczial nogo perevoda [The phenomenon of linguistic interference in the study of special translation]: avtoref. dis. kand. filolog. nauk. Moskva: MGU, 24 s. 